\title{
Don't Put All of Your Alums in One Basket: College Admissions Decisions as a Portfolio Choice Problem
}

\author{
Logan Dahl ${ }^{1} \&$ Daniel K.N. Johnson ${ }^{2}$ \\ ${ }^{1}$ Project Manager, Epic, USA \\ ${ }^{2}$ Economics \& Business Department, Colorado College, Colorado Springs, USA \\ Correspondence: Daniel K.N. Johnson, Schlessman Professor of Economics, Economics \& Business Department, \\ Colorado College, 14 E Cache La Poudre Street, Colorado Springs, CO 80903, USA.
}

Received: June 29, 2016

Accepted: July 13, 2016

Online Published: July 18, 2016

doi:10.5430/ijfr.v7n4p175

URL: http://dx.doi.org/10.5430/ijfr.v7n4p175

\begin{abstract}
We consider philanthropy by college alums from an innovative and provocative perspective: what if prospective college students were considered members of asset classes with different risk-return combinations? Using forty years of merged admissions-philanthropy records on students at a highly selective liberal arts college, we estimate the simple financial model that this allegory implies. We find benefits to diversification, identify the slope of the market risk-return line, and point out the most (and least) attractive potential students in terms of their projected future donations.
\end{abstract}

Keywords: admissions, alum, portfolio, CAPM

\section{Introduction}

Alumni giving has become increasingly important for institutions of higher education, accounting for roughly fifteen percent of all private funding for higher education, or roughly $\$ 4$ billion (Council for Aid to Education, 2012). Even as alumni giving has been rising (Kaplan, 2007), the participation rate of alumni giving back to their alma mater has been falling, while those who donate choose to contribute larger amounts (Engagement Strategies Group, 2010). Given this dynamic, there is enormous value in finding the right potential donors; it is unsurprising that academic models and consulting companies have tackled the question with fervor.

This paper models alumni giving from a unique perspective, treating college admissions decisions as a portfolio choice problem, where prospective students are members of asset classes with rates of risk and return measured $a$ priori by the propensity of each asset class to subsequently donate to their institution. While we do not suggest that admissions decisions are (or should be) made in this manner, we reflect on the implications of a simple Capital Asset Pricing Model (CAPM) framework using data provided by a selective liberal arts college.

Academic research clearly describes patterns in alumni giving (e.g. Bruggink and Siddiqui,1995; Okunade et al., 1994; Wunnava and Lauze, 2001), identifying descriptive variables that predict philanthropy (Lara and Johnson, 2014; Meer, 2011; Meer and Rosen, 2007; Clotfelter, 2003; Monks, 2003; Cunningham and Cochi-Ficano, 2002; Forbes and Zampelli, 1997; Lindahl and Winship, 1992). Obvious demographic variables such as age, gender, ethnicity, and marital status have been shown to have predictive power, as have activities while in school (major, involvement in college sports, GPA, affiliation with a fraternity or sorority, certain kinds of financial aid) and post-graduation factors (time since graduation, number of relatives at one's alma mater, reunion years, willingness to share contact information with the college, response to college surveys, highest degree attained, participation in student government, induction into honorary societies, participation in alumni activities).

In contrast, no study has proposed a predictive model based purely on factors known before the student enters higher education. Unlike the literature, our intention is not to explain or predict alumni giving, but to create asset classes of potential students based on characteristics observable among prospective students at least 5 years before they have the ability to donate as an alum.

\section{Method}

We use only five variables to categorize individuals, all self-identified on 17,000 admissions applications to 
Colorado College between 1963 and 2011: gender, race, athletic participation, SAT scores, and age. These were merged with total donations by each individual made to date, as summarized in Table 1. Notice that the entire population is fairly homogeneous in race and age, but has some variation in gender, athletics and SAT scores. Also notice that donations, or expected returns, represent an extremely skewed distribution with a median donation below three dollars and an average above four hundred dollars.

There are several limitations in the data, including missing values for a small subset which we assume to be randomly distributed. Frustratingly, the records do not record the amount of each donation, but simply the total over time, so do not permit detailed analysis of time paths or even time-discounted values of total donations.

Table 1. Summary statistics

\begin{tabular}{|c|c|}
\hline \multicolumn{2}{|c|}{ Gender } \\
\hline Male & $47 \%$ \\
\hline Female & $53 \%$ \\
\hline \multicolumn{2}{|c|}{ Race } \\
\hline White & $85 \%$ \\
\hline African-American & $2 \%$ \\
\hline Hispanic & $5 \%$ \\
\hline Asian-American & $3 \%$ \\
\hline Native American & $1 \%$ \\
\hline Other/Not Reported & $4 \%$ \\
\hline \multicolumn{2}{|c|}{ Athletics } \\
\hline Active & $26 \%$ \\
\hline Not Active & $74 \%$ \\
\hline \multicolumn{2}{|c|}{ SAT scores } \\
\hline Mean score & 1178 \\
\hline Minimum score & 500 \\
\hline Maximum score & 1600 \\
\hline Standard deviation & 149 \\
\hline \multicolumn{2}{|c|}{ Age } \\
\hline Young & $2 \%$ \\
\hline Average & $81 \%$ \\
\hline Old & $4 \%$ \\
\hline Not reported & $13 \%$ \\
\hline \multicolumn{2}{|c|}{ Expected return or donation } \\
\hline Mean donation & $\$ 420.12$ \\
\hline Median donation & $\$ 2.58$ \\
\hline Standard deviation & $\$ 3,953.79$ \\
\hline
\end{tabular}

Treating each prospective student as a stock, we built asset classes to plot on a risk-return graph; the slope of the computed "line of best fit" will describe the relationship between risk and return for different asset classes. That fitted line will not be a true Security Market Line or Capital Allocation Line, due to a lack of overall market knowledge to inform the value of beta (Sharpe, 1964). While we are fully aware of the limitations of the CAPM model for predicting investor behavior (e.g. Fama and French, 1995; Fama and French, 2006; Campbell and Vuolteenaho, 2004), our goal here is not to predict or even to recommend investment-type decisions but merely to explore the parallel between financial assets and alums as potential investments using the traditional CAPM risk-return relationship.

To create mutually exclusive and exhaustive asset classes, we divided continuous variables into categories: SAT 
scores $(0-800 ; 801-1000 ; 1001-1200 ; 1201-1400 ; 1401-1600)$ and age $(0-16 ; 17-22 ; 23-99$; not reported). For groups that had too few members, we aggregated SAT scores into two categories $(0-800 ; 801-1600)$ to create larger groups. We ultimately evaluate 300 separate asset classes, each representing twenty or more individuals.

In preliminary data exploration, we discovered that eight individuals in our dataset were major donors, and their presence determined all subsequent tests and results. We elected to omit them from consideration as they spanned many asset categories but clearly masked the underlying pattern in the remaining 16, 992 observations.

\section{Results}

A standard OLS regression on the asset classes, expressing expected return of an asset class as a function of a constant and the standard deviation of that asset class yields the results in Table 2. Standard tests show statistical significance at the $95 \%$ confidence level. The same information is graphed in Figure 1 as a scatterplot of asset groups and the line of best fit.

Table 2. Simple linear regression results

(Expected return as dependent variable)

\begin{tabular}{llll}
\hline Variable & Coefficient & t-statistic & \\
\hline Standard deviation & 0.136 & $(10.33)$ & $* * *$ \\
\hline Constant & 56.560 & $(3.93)$ & $* * *$ \\
\hline R-squared & & 0.87 & \\
\hline F-statistic & & 106.61 & $* * *$ \\
\hline
\end{tabular}

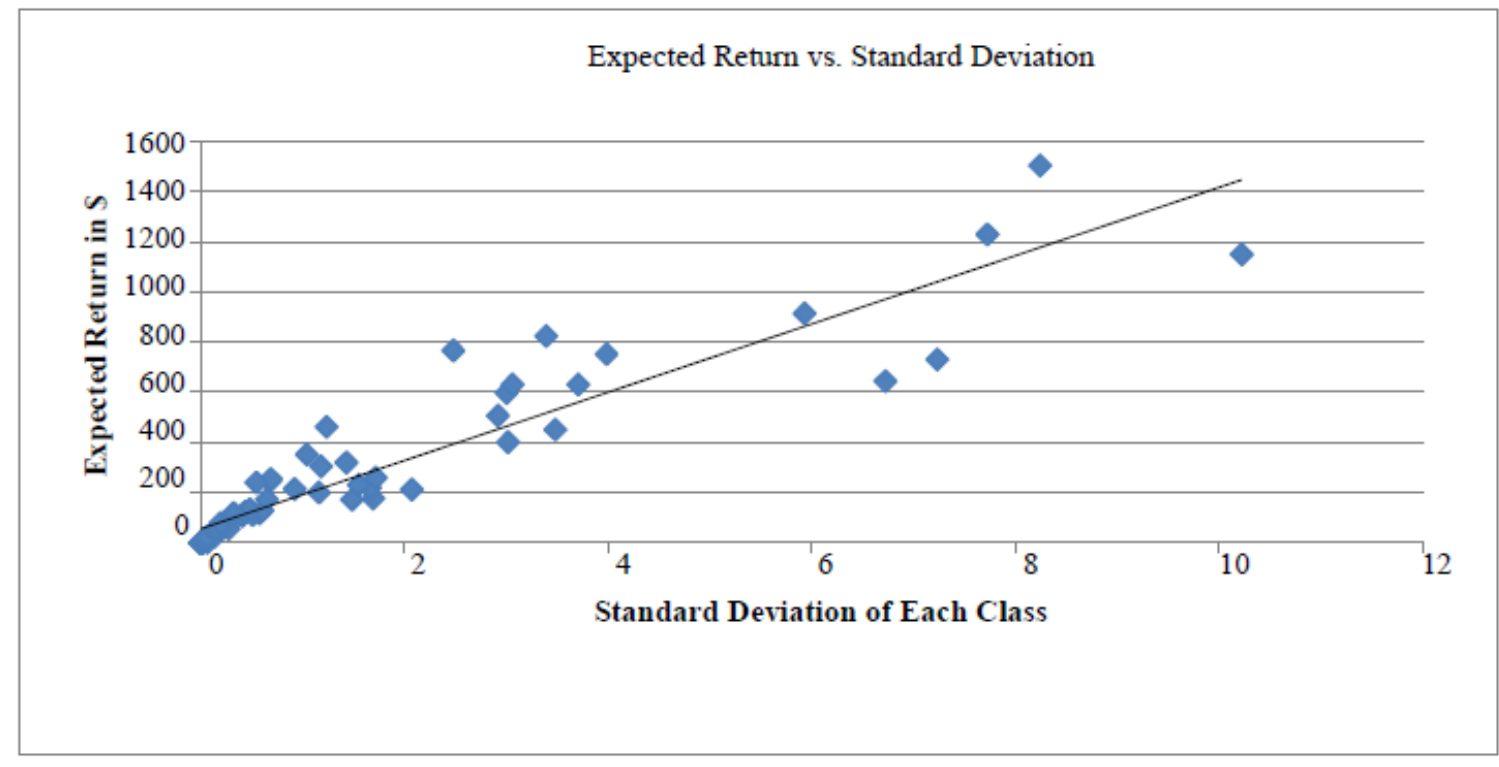

Figure 1. Regression line and asset classes

Notice that the risk-return line appears as anticipated by financial asset theory. The analogue to the risk-free rate of return is $\$ 56.56$ in this case, which we can perhaps liken to a "graduation fee" (i.e. every alum averages at least this donation amount, even in the lowest-risk groups of admitted students). Beyond that risk-free rate, for each dollar of standard deviation in philanthropic giving that the institution accepts, they can expect an average additional return of $\$ 0.16$ (or $0.2 \%$ ). In sum, the curve is comparable to risk-return tradeoffs in other financial assets: Mensah (2015) calculated 0.02 to $0.12 \%$ for 19 th century stock markets, French (2015) calculated 0.1 to $0.3 \%$ for contemporary U.S. and ASEAN stock markets, Atanasov and Nitschka (2015) calculated a range of 0.01 to $0.38 \%$ for most major world currencies. 
To play the financial allegory further, wise investors aiming to minimize risk for a given return should invest in asset classes above the line, and divest themselves of assets below the line. Table 3 lists the "best" and "worst" investments for the institution, in terms of risk-return. Naturally, we are not advocating for a particular admissions policy, but rather identifying the groups of students most (and least) likely to return favorable financial benefits to the institution, taking into account the levels of predictable risk of future donations inherent in students who share their characteristics.

Table 3: "Best" and "Worst" asset classes

\begin{tabular}{|c|c|}
\hline Groups farthest above CAPM line & Groups farthest below CAPM line \\
\hline $\begin{array}{l}\text { White male athletes } \\
\text { with SAT scores } 800-999 \\
\text { admitted at traditional age }\end{array}$ & $\begin{array}{l}\text { White female non-athletes } \\
\text { with SAT scores } 1000-1199 \\
\text { admitted at traditional age }\end{array}$ \\
\hline $\begin{array}{l}\text { White male athletes } \\
\text { with SAT scores } 1000-1199 \\
\text { admitted at traditional age }\end{array}$ & $\begin{array}{l}\text { White female athletes } \\
\text { with SAT scores } 1000-1199 \\
\text { admitted at traditional age }\end{array}$ \\
\hline $\begin{array}{l}\text { African-American female non-athletes } \\
\text { with unreported SAT scores } \\
\text { admitted at traditional age }\end{array}$ & $\begin{array}{l}\text { Unreported ethnicity male non-athletes } \\
\text { with SAT scores } 800-1600 \\
\text { admitted at traditional age }\end{array}$ \\
\hline $\begin{array}{l}\text { White female athletes } \\
\text { with SAT scores } 800-1600 \\
\text { admitted at younger than traditional age }\end{array}$ & $\begin{array}{l}\text { White female athletes } \\
\text { with unreported SAT scores } \\
\text { admitted at traditional age }\end{array}$ \\
\hline
\end{tabular}

Notice that there are no clear correlations between subsequent philanthropy and ethnicity, SAT scores or age alone; rather, it is the combination of those variables into specific cohorts that make particular asset classes more or less risky for a given expected philanthropic return (a fact true of financial assets as well, e.g. Fama and French, 2006). Most importantly, it is unwise to extrapolate these results to assert universal truths, because these asset classes are clearly functions of the students who elected to apply to this particular institution and who in turn were accepted and became alums. However, it is comforting to the authors that there are empirical gains to diversity and to diversification, because a student body carefully composed of only members of the top four groups in Table 3 would outperform the average in terms of risk and return while providing for a student body representing ethnic, gender, athletic and scholastic diversity.

\section{Discussion}

Coupling admissions data and fundraising data from a small liberal arts college, we grouped alums into "asset classes" based on their inherent characteristics, and evaluated those groups according to their expected return and standard deviation. A simple linear regression shows a risk-return relationship similar to that facing an investor in a purely financial decision. In short, there is a tradeoff between safer and more spectacular financial returns from alums. We find this result comforting; just as in a financial portfolio, there appear to be benefits, financial in this case, from diversification (and from diversity more broadly).

There are obviously numerous points for improvement in this study. There is possible refinement of the classification of individuals (most notably in the "not reported" categories of our demographic data, but potentially elsewhere as well). The CAPM framework that we consider is naturally inordinately simple, and could be replaced with more intricate financial models. We consider only the financial implications of admitted students, and even then not very adeptly as the data collapse all contributions over time into a single total.

Clearly, the admissions decision is (and should be) more complicated than a portfolio allocation decision based on financial risk and return. There is need for replicative research, to confirm that the alumni of other institutions follow similar risk-return tradeoffs, to ascertain whether the slope of the CAPM frontier is similar at selective or public institutions, to reflect on what causes the tradeoff in the first place (i.e. what are the attributes of each 'asset class' that position them where they occur on the graph. After all of that exploration, there might be a policy advocacy recommendation, on how best to build diversity in the current entering class while ensuring financial stability that will promote diversity in subsequent entering classes as well.

We hope that this innovative approach might stimulate further research and discussion about philanthropy in higher 
education, about how the financial models which underpin our investment strategies might be employed to offer assistance in an economic climate which threatens the resources upon which higher education relies.

\section{References}

Atanasov, V., \& Nitschka, T. (2015). Foreign Currency Returns and Systematic Risks. Journal of Financial and Quantitative Analysis, 50(1-2), 231-250. http://dx.doi.org/10.1017/S002210901400043X

Campbell, J.Y., \& Vuolteenaho, T. (2004). Bad Beta, Good Beta. The American Economic Review, 94(5), 1249-1275. http://dx.doi.org/10.1257/0002828043052240

Coltfelter, C. (2003). Alumni Giving to Elite Private Colleges and Universities. Economics of Education Review, 22, 109-20. http://dx.doi.org/10.1016/S0272-7757(02)00028-6

Council for Aid to Education. (2006). Voluntary Support of Education. New York.

Council for Aid to Education. (2012). Voluntary Support of Education. New York.

Cunningham, B., \& Cochi-Ficano, C. (2002). The Determinants of Donative Revenue Flows from Alumni of Higher Education: An Empirical Inquiry. The Journal of Human Resources, 37(3), 540-569. http://dx.doi.org/10.2307/3069681

Fama, E.F., \& French, K.R. (1995). Size and Book-to-Market Factors in Earnings and Returns. The Journal of Finance, 50(1), 131-155. http://dx.doi.org/10.1111/j.1540-6261.1995.tb05169.x

Fama, E.F., \& French, K.R. (2006). The Value Premium and the CAPM. The Journal of Finance, 61(5).

French, J. (2015). Estimating Time-Varying Beta Coefficients: An Empirical Study of U.S. and ASEAN portfolios. Stamford International University Working Paper.

Holmes, J., Meditz, J., \& Sommers, P. (2008). Athletics and alumni giving: Evidence from a highly selective liberal arts college. Journal of Sports Economics, 9(5), 538-552. http://dx.doi.org/10.1177/1527002507313896

Lara, C., \& Johnson, D.K.N. (2014). The Anatomy of a Likely Donor: Econometric Evidence on Philanthropy to Higher Education. Education Economics, 22(3), 293-304. http://dx.doi.org/10.1080/09645292.2013.766672

Lindahl, W.E., \& Winship, C. (1992). Predictive Models for Annual Fundraising and Major Gift Fundraising. Nonprofit Management and Leadership, 3(1), 43-64. http://dx.doi.org/10.1002/nml.4130030105

Marr, K., Mullin, C., \& Siegfried, J. (2005). Undergraduate Financial Aid and Subsequent Alumni Giving Behavior. The Quarterly Review of Economic and Finance, 45(1), 123-143. http://dx.doi.org/10.1016/j.qref.2003.08.005

Meer, J. (2011). Brother, can you spare a dime? Peer pressure in charitable solicitation. Journal of Public Economics, 95(7-8), 926-941. http://dx.doi.org/10.1016/j.jpubeco.2010.11.026

Meer, J., \& Rosen, H. (2007). Altruism and the Child-Cycle of Alumni Donations. CEPS Working Paper 150.

Mensah, L. (2015). Size, Beta, Average Stock Return Relationship: 19th Century Evidence. Journalof Finance and Bank Management, 201(5), 117-133. http://dx.doi.org/10.15640/jfbm.v3n1a11

Monks, J. (2002). Patterns of Giving to One's Alma Mater among Young Graduates from Selective Institutions. Economics of Education Review, 22(2), 121-30. http://dx.doi.org/10.1016/S0272-7757(02)00036-5

Okunade, A., Wunnava, P., \& Walsh, R. Jr. (1994). Charitable Giving of Alumni: Micro-Data Evidence from a Large Public University. American Journal of Economics and Sociology, 53(1), 73-84. http://dx.doi.org/10.1111/j.1536-7150.1994.tb02674.x

Sharpe, W.F. (1964). Capital Asset Prices: A Theory of Market Equilibrium under Conditions of Risk. The Journal of Finance, 19(3), 425-442. http://dx.doi.org/10.1111/j.1540-6261.1964.tb02865.x

Wesley, L., \& Winship, S. (1992). Predictive Models for Annual Fundraising and Major Gift Fundraising. Nonprofit Management and Leadership, 3(1), 43-64. http://dx.doi.org/10.1002/nml.4130030105

Winston, G. (1999). Subsidies, Hierarchies and Peers: the Awkward Economics of Higher Education. Journal of Economic Perspectives, 13(1), 13-36. http://dx.doi.org/10.1257/jep.13.1.13

Wunnava, P., \& Lauze, M. (2001). Alumni Giving at a Small Liberal Arts College: Evidence from Consistent and Occasional Donors. Economics and Education Review, 20, 533-43. 